\title{
Choriocarcinoma presenting following a molar pregnancy and preterm vaginal delivery: rarest of rare case
}

\author{
Sindhu N. R., Shradha Shetty* \\ Department of Obstetrics and Gynaecology, KMC, Mangalore, Karnataka, India \\ Received: 10 November 2020 \\ Revised: 11 January 2021 \\ Accepted: 12 January 2021 \\ *Correspondence: \\ Dr. Shradha Shetty, \\ E-mail: nrsindhugowda@gmail.com \\ Copyright: ( ) the author(s), publisher and licensee Medip Academy. This is an open-access article distributed under \\ the terms of the Creative Commons Attribution Non-Commercial License, which permits unrestricted non-commercial \\ use, distribution, and reproduction in any medium, provided the original work is properly cited.
}

\begin{abstract}
Choriocarcinoma is the aggressive histologic type of GTN and is characterized by vascular invasion and metastases of widespread. Choriocarcinoma metastasizes hematogenously. Suction and evacuation were done on admission. BetahCG was $67900 \mathrm{mIU} / \mathrm{ml}$ and $144523 \mathrm{mIU} / \mathrm{ml}$ on day 1 and day 3 respectively and histopathology showed Choriocarcinoma. This is very unusual case of reviewing sequential events. It was difficult to detect is it new pregnancy or choriocarcinoma. Investigators were biased with high beta-hCG values indicating malignancy. So there was differential diagnosis as choriocarcinoma based on history of molar pregnancy and increasing beta-hCG value and also dictum of 'non molar pregnancy following live birth is always choriocarcinoma. However histopathology report suggested choriocarcinoma and was diagnostic.
\end{abstract}

Keywords: Choriocarcinoma, Molar pregnancy, preterm vaginal delivery

\section{INTRODUCTION}

Choriocarcinoma is the aggressive histologic type of GTN and is characterized by vascular invasion and metastases of widespread. Choriocarcinoma metastasizes hematogenously. ${ }^{1}$ Asian women have more aggressive disease and higher incidence of 1/389 live births and nonAsian women with 1/752 live births. Choriocarcinoma has higher incidence in women less than 18 years and slightly less incidence women more than 45 years. ${ }^{2}$

\section{CASE REPORT}

A 23 year old P1L1A2 reported to labour room with bleeding per vagina two months following a preterm vaginal delivery with uneventful postpartum period. Her vitals were stable, systemic and abdominal examination was normal.
Bimanual examination suggested bulky uterus. Urine pregnancy test done was positive. Ultrasound scan done showed endometrial thickness of $20 \mathrm{~mm}$ with increased vascularity with no fetal pole or yolk sac, features suggestive of retained products of conception. Suction and evacuation were done. Beta-hCG was $67900 \mathrm{mIU} / \mathrm{ml}$ and $144523 \mathrm{mIU} / \mathrm{ml}$ on day 1 and day 3 respectively and histopathology showed choriocarcinoma.

On probing, patient revealed that she had a history of Molar pregnancy three years ago and suction and evacuation was done with histopathology of complete mole but patient failed to go for follow up. CT imaging showed brain metastasis with stage 4B and risk score 10 . She received 3 cycles of chemotherapy with EMACO regimen. 


\section{Histopathological examination}

Nest atypical cytotrophoblasts admixed with nest of syncytiotrophoblasts and extravillous trophoblasts cytotrophoblasts show severe nuclear pleomorphism, large nucleoli and chorionic villi was absent (Figure 1).

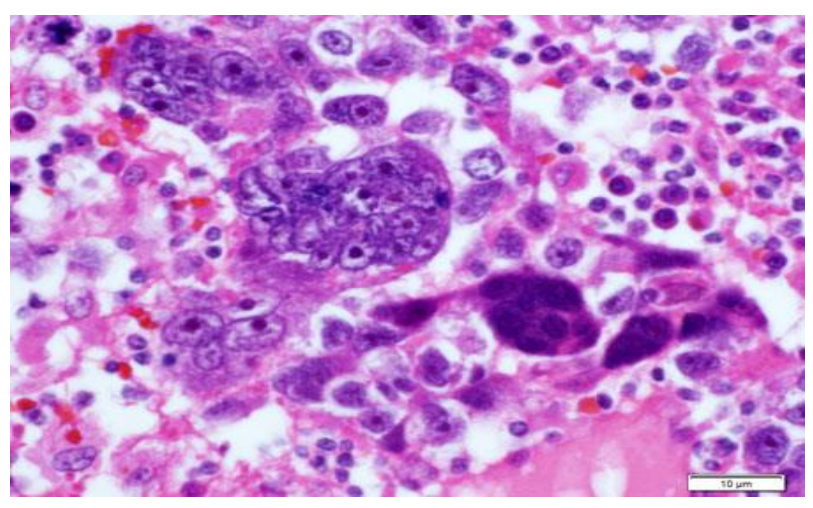

Figure 1: Histopathological examination of choriocarcinoma.

\section{DISCUSSION}

Postpartum choriocarcinoma is a very rare complication of pregnancy with a reported UK incidence of 1 in 50,000 live births. ${ }^{3}$ This patient presented during postpartum period, that is two months after delivery with bleeding per vagina, with urine pregnancy test done was positive. Ultrasound scan showed endometrial thickness of $20 \mathrm{~mm}$ with increased vascularity with no fetal pole or yolk sac, features suggestive of retained products of conception. Pregnancy and related disorders must be the initial diagnosis in young women with irregular vaginal bleeding as most of the women with vesicular mole (benign form of choriocarcinoma) present with irregular vaginal bleeding and diagnosed as delayed miscarriage or anembryonic pregnancy, as in this patient. ${ }^{4,5}$ Dobson et al. ${ }^{6}$ reported nine cases of postpartum choriocarcinoma and in their series the time interval from antecedent pregnancy to onset of symptoms (vaginal bleeding) was 0-12 weeks. The same authors also reported a patient who was on progestogens for irregular vaginal bleeding postpartum. ${ }^{6}$

On admission, day 1 beta-hCG was $67900 \mathrm{mIU} / \mathrm{ml}$ value made us to keep in as mind as either molar pregnancy or gestational trophoblastic tumour, however suction and evacuation done and products sent for histopathology, later b HCG was repeated on Day 3 was $144523 \mathrm{mIU} / \mathrm{ml}$. Increasing trend of beta-HCG alerted of GTN, however histopathology report showed Choriocarcinoma and confirmed the diagnosis. In view of the maternal risks associated with ectopic and molar pregnancy, it was recommended that tissue obtained at the time of uterine evacuation (medical or surgical) has to be sent for histologic examination. ${ }^{7}$ On probing, patient revealed that she had a history of molar pregnancy three years ago and suction and evacuation was done with histopathology of complete mole and patient was called back for beta-HCG follow up, but patient failed to go for follow up, there was no availability of previous records. CT imaging showed brain metastasis with stage $4 \mathrm{~B}$ and risk score 10 . She received 3 cycles of chemotherapy with EMACO regimen.

The prognosis for women with choriocarcinoma after non-molar pregnancies may be worse, in part owing to delay in diagnosis or advanced disease, such as liver or CNS disease and this patient had metastases in the lung and liver at presentation. 8,9

\section{CONCLUSION}

It can be concluded from current case study that if any patient comes with bleeding pv in postpartum period with urine pregnancy test positive without viable pregnancy, always to be investigated for pregnancy related causes including GTN. Histopathogy report to be followed up always after surgical or medical management, since malignancy requires further management.

\section{ACKNOWLEDGMENTS}

Authors would like to thank participant who consented to be a part of our case report.

\section{Funding: No funding sources \\ Conflict of interest: None declared \\ Ethical approval: Not required}

\section{REFERENCES}

1. Seckl MJ, Sebire NJ, Berkowitz RS. Gestational trophoblastic disease. Lancet 2010;376:717.

2. Feltmate CM, Genest DR, Wise L. Placental site trophoblastic tumor: a 17-year experience at the New England trophoblastic disease center. Gynecol Oncol. 2001;82:415.

3. Bagshawe KD, Dent J, Webb J. Hydatidiform mole in England and Wales in 19731983. Lancet. 1986;2(8508):673-7.

4. Green top guideline No 38 management of gestational trophoblastic Neoplasia. Available at: http://www.rcog.org.uk/files/rcog-corp/GT38 ManagementGestational0210.pdf. Accessed on 20 July 2020.

5. Fowler DJ, Lindsay I, Seckl MJ. Routine preevacuation ultrasound diagnosis of hydatidiform mole: experience of more than 1000 cases from a regional referral center. Ultrasound Obstet Gynecol. 2006;27:56-60.

6. Dobson LS, Gillespie AM, Coleman RE. The presentation and management of post-partum choriocarcinoma. Br J Cancer. 1999;79:1531-3.

7. Management of early pregnancy loss. Green-top guideline No. 25. Available at: www.rcog.org.uk/ womenshealth/clinical-guidance/management-early- 
pregnancy-loss-green-top-25. Accessed on 20 July 2020.

8. Powles T, Young A, Sammit A. The significance of the time interval between antecedent pregnancy and diagnosis of high risk gestational trophoblastic tumours. Br J Cancer. 2006;95:1145-7.

9. Ma Y, Xiang Y, Wan XR. The prognostic analysis of 123 post partum choriocarcinoma cases. Int J Gynecol Cancer. 2008;18:1097-101.
Cite this article as: Sindhu NR, Shetty S.

Choriocarcinoma presenting following a molar pregnancy and preterm vaginal delivery: rarest of rare case. Int J Reprod Contracept Obstet Gynecol 2021;10:781-3. 